\title{
3D heritage visualisation and the negotiation of authenticity: the ACCORD project
}

Corresponding author: Siân Jones, Professor of Environmental History and Heritage, Centre for Environment, Heritage and Policy, Division of History and Politics, Pathfoot Building, University of Stirling, FK9 4LA, UK. Email: sian.jones@stir.ac.uk http://orcid.org/0000-0001-6157-7848

Stuart Jeffrey, Research Fellow in Heritage Visualisation, Glasgow School of Art, 167

Renfrew St, Glasgow G3 6RQ, UK. Email: stuart.jeffrey@,gsa.ac.uk

http://orcid.org/0000-0003-2084-4174

Mhairi Maxwell, Research Associate, Glasgow School of Art, 167 Renfrew St, Glasgow G3 6RQ, UK. Email: mhairi.maxwell@btinternet.com

http://orcid.org/0000-0003-1740-8590

Alex Hale, Archaeologist, Historic Environment Scotland, John Sinclair House, 16 Bernard Terrace, Edinburgh EH8 9NX, UK. Email: alex.hale@hes.scot

http://orcid.org/0000-0002-6560-4003

Cara Jones, Adopt-a-Monument Project Manager, Archaeology Scotland, 1A, Stuart House, Eskmills Pk, Station Rd, Musselburgh EH21 7PB, UK. Email:

c.jones@archaeologyscotland.org.uk

This work was supported by the Arts and Humanities Research Council under grant AH/L007533/1. The data is archived with the Archaeology Data Service, https://doi.org/10.5284/1042733

This is a pre-publication version. The published article can be accessed here: http://dx.doi.org/10.1080/13527258.2017.1378905

To cite this article: Siân Jones, Stuart Jeffrey, Mhairi Maxwell, Alex Hale \& Cara Jones (2017): 3D heritage visualisation and the negotiation of authenticity: the ACCORD project, International Journal of Heritage Studies, DOI: 10.1080/13527258.2017.1378905 


\title{
3D heritage visualisation and the negotiation of authenticity: the ACCORD project
}

\author{
Abstract: \\ This article examines the question of authenticity in relation to 3D visualisation of \\ historic objects and monuments. Much of the literature locates their authenticity in the \\ accuracy of the data and/or the realism of the resulting models. Yet critics argue that 3D \\ visualisations undermine the experience of authenticity, disrupting people's access to the \\ materiality, biography and aura of their historic counterparts. The ACCORD project takes \\ questions of authenticity and 3D visualisation into a new arena - that of community \\ heritage practice - and uses rapid ethnographic methods to examine whether and how \\ such visualisations acquire authenticity. The results demonstrate that subtle forms of \\ migration and borrowing occur between the original and the digital, creating new forms \\ of authenticity associated with the digital object. Likewise, the creation of digital models \\ mediates the authenticity and status of their original counterparts through the networks of \\ relations in which they are embedded. The current pre-occupation with the binary \\ question of whether 3D digital models are authentic or not obscures the wider work that \\ such objects do in respect to the cultural politics of ownership, attachment, place-making \\ and regeneration. The article both advances theoretical debates and has important \\ implications for heritage visualisation practice.
}

Keywords: authenticity, 3D modelling, digital heritage visualisation, co-production, community 


\section{Introduction}

Media forms are constantly calling into question each other's ability to represent the authentic, and these remediations raise the possibility of the decay of aura, the loss of authenticity of experience. (Bolter et al. 2006, 34)

Authenticity has long been seen as an intrinsic and immutable dimension of tangible historic objects, monuments and landscapes; an integral aspect of their significance, their truthfulness, and their genuineness. In authorised museum and heritage discourses, there has been an overwhelming emphasis on material authenticity, with the integrity or 'true' nature of objects defined in relation to their origins, provenance and fabric (Cameron 2007, 52; Jones 2010,184$)$. In contrast, the authenticity of physical replicas and reconstructions has a much more checkered and ambivalent history (Foster and Curtis 2015; Fyfe 2004; Rabinowitz 2015). Whilst fluctuating according to their modes of production, accuracy, institutional associations and biographical trajectories, their authenticity and value are almost always seen as secondary, and indeed a potential threat, to the original objects they represent. Digital visualisations of historic objects and monuments, which can be seen as virtual replicas or reconstructions, often acquire a similarly complex and ambivalent status (Cameron 2007). However, recent research suggests that apparently clear cut distinctions between originals and replicas, both physical and digital, are far more complex.

The extent to which the authenticity of originals is intrinsic and immutable has been questioned. It has been argued that authenticity is in large part culturally constructed, being constituted through regimes of value associated with authorising institutions such as museums, art galleries and the international art market (Bruner 2007; Holtorf and Schadla Hall 1999; Lindholm 2008). In terms of the experience of authenticity, aging, patina and material decay are also important, creating a diffuse sense of 'pastness' (Holtorf 2013; Douglas-Jones et al. 2016). Finally, ethnographic research reveals that authenticity is produced and negotiated through networks of relationships between people, places and things (Dicks 2000; Jones 2010; Jones and Yarrow 2013; Macdonald 2013).

Just as the intrinsic authenticity and value of originals is problematised, so the inauthenticity of replicas has been questioned. From various perspectives, studies have shown that physical replicas can acquire authenticity and value, depending on their modes of production and consumption, and the networks of institutional and individual relations they are embedded in (e.g. Foster and Curtis 2013; Holtorf and Schadla-Hall 1999; Latour and Lowe 2009). Likewise in debates surrounding digital media, the idea that virtual representations signal the end of authenticity has been challenged (e.g. Cameron 2007; Gillings 2005; Jeffrey 2015), or at least reconfigured as 'the experience of aura is alternately called into question and reaffirmed' (Bolter et al. 2006: 22). 
In this article, we examine the question of authenticity in relation to digital visualisation of historic objects and monuments in the context of participatory community practices. We draw on the results of the innovative ACCORD project (Archaeological Community Co-Production of Research Resources), which examined the opportunities and implications of collaborative, community-based, digital recording and modelling, using the techniques of photogrammetry and reflectance transformation imaging. The methodologies underpinning community co-design and co-production in the ACCORD Project are discussed in detail elsewhere (Jeffrey et al. 2015), whilst another article focuses on their role in the production of value and sense of place (Jeffrey et al. in prep). Here we use the rapid ethnographic research conducted alongside the project to explore the relationship between 3D digital models and authenticity.

This research provides a substantial body of qualitative evidence demonstrating that digital objects can acquire authenticity and value; something that until now has been largely confined to theoretical propositions. Whilst distinctions between originals and 3D models are upheld, the research shows that it is a mistake to view these in terms of fixed attributes. Rather digital records and objects become bound up in complex and dynamic networks of relationships. Importantly, these allow for subtle forms of migration and borrowing, alongside the generation of new forms of value and authenticity. The community co-design and co-production employed in the ACCORD project is a key part of this process, creating relationships between people, places and objects often expressed in forms of identity and belonging. Thus, whilst much of the literature on the authenticity and value of digital media focuses on accuracy, resolution, aesthetics and consumption (see Bolter et al. 2006; Gartski 2016), this research shows that modes of production and participatory practice are equally if not more important. The results challenge received assumptions about authenticity and new digital media, and advance related philosophical and theoretical debates. They also have important ramifications for the application of digital heritage visualisation in practice.

\section{Authenticity and digital representation}

Before turning to the ACCORD project in detail, we interrogate the current debates surrounding digital media and authenticity in more depth and explain our approach to these issues. Broadly speaking, authenticity refers to the quality of being authentic, that is, real, original, truthful, or genuine; 'really proceeding from its stated source' (Oxford English Dictionary 2002, 153). Authorised heritage and museum discourses still treat authenticity as something intrinsic to historic buildings, monuments and objects and lacking or derivative in the case of replicas. As noted in the introduction, constructivist critiques have dismantled this distinction to some extent, but the intimate relationship between materiality and conceptions of authenticity remains firm. Historic fabric is objectified as a container of authenticity and a battery of techniques applied to differentiating the 'real' or 'genuine', from the 'fake'. Indeed, even recent research challenging essentialist notions of authenticity suggests that the specific biographies and materialities of historic objects are important in how people 
experience and negotiate authenticity (e.g. Holtorf 2013; Jones 2010 and 2016). In particular, weathering and patina are significant elements in people's experience of authenticity (Douglas-Jones et al. 2016). It is not surprising therefore that the 'weirdness' of digital objects creates questions about their authenticity (Jeffrey 2015, 147). Lacking either physical substance, or a specific physical locale, they can seem like otherworldly, free floating representations. Furthermore, whilst they can offer a representation of the physical signs of age, digital objects themselves appear impervious to the ravages of time, even bearing infinite reproduction apparently without attenuation (ibid.). For these reasons their authenticity is regarded with suspicion and their existence is even seen as a threat to the unique, 'original' historic forms they represent.

The work of Benjamin has been particularly influential in debates about digital authenticity (Bolter et al. 2006; Cameron 2007; Garstki 2016; Jeffrey 2015; Rabinowitz 2015). Writing in the early twentieth century in response to new technological developments such as photography and cinema, Benjamin argued that mechanical reproduction undermines the uniqueness of the original art object, which in turn leads to the decay of aura, along with the sense of awe and reverence associated with it. For Benjamin (1968 [1936]), 221) the aura or authenticity of a thing:

\footnotetext{
...is the essence of all that is transmissible from its beginning, ranging to its substantive duration to its testimony to the history it has experienced. Since the historical testimony rests on the authenticity, the former, too is jeopardized by reproduction when substantive duration ceases to matter.
}

The authenticity of an object is thus associated with its unique position in space and time, and the biography it encapsulates. Although Benjamin highlighted the liberatory political possibilities of mechanical reproduction, those applying his ideas to mass digital media have focused primarily on its potential to destabilise the 'real' and the 'true' (Cameron 2007, 5051). Digital models and visualisations of historic objects, buildings and monuments are often portrayed as inauthentic 'digital terrorists' (ibid., 51), or in a more positive sense useful surrogate records that remain highly dependent on their physical referents. In this latter sense, the degree of accuracy, objectivity, and/or realism of digital records and visualisations inevitably remain key preoccupations, notwithstanding their separation and distinction from their tangible counterparts (e.g. Gartski 2016; Rabinowitz 2015).

Nevertheless, as noted in our introduction these hard and fast distinctions between digital historical objects and their physical counterparts have been challenged. In their work on physical copies of artworks produced through intermediary digital techniques, Latour and Lowe (2011) directly challenge Benjamin's thesis, arguing that some part of the aura of the original object can 'migrate' to its replicas. They propose that some forms of replication facilitate this migration more than others and much depends on the different degrees of effort, cost and technological sophistication employed (ibid., 7-8). They also argue that the physical 
and cultural contexts in which copies are encountered are important in determining the degree to which they acquire aura or authenticity (ibid., 10-11). Jeffrey $(2015,148)$ builds on Latour and Lowe's argument and proposes that aura can also migrate to digital copies in and of themselves, through both attention to the aesthetics of digital visualisations and, foreshadowing this research, active community participation in their production. Others in turn have suggested that digital historical objects can accrue their own forms of authenticity or aura over time, because 'the digital historical object is a creative work in its own right with a history and provenance' (Cameron 2007, 67).

The ACCORD project sheds new light on the question of if, when, and how digital 3D historic objects acquire authenticity. Our focus is on how people experience authenticity in relation to 3D models. Thus, we are not concerned with characteristics such as accuracy, objectivity and realism per se, except in so far as they inform the production and negotiation of authenticity. We also treat aura as a specific aspect of the experience of authenticity related to biographical uniqueness and a simultaneous sense of distance and connection associated with heritage objects; what one of us has referred to as the 'thrill of proximity' (Jeffrey 2015, 147). In addition to exploring whether or not digital 3D visualisations of historic objects, monuments and places can acquire authenticity or aura, we also ask what these visualisations $d o$. In what ways do they impact on the authenticity of their 'original' counterparts and their ongoing biographical trajectories? Furthermore, to what extent do they create, extend and/or reinforce networks of relations between people, places and things, and in so doing mediate the experience of authenticity (cf. Jones 2010; Jones and Yarrow 2013; Macdonald 1997b, 2013)?

Before we examine these questions in more depth, we discuss the research practices and methodologies used in the ACCORD project, starting with a brief summary of approaches to digital visualisation and public engagement. We then introduce the community heritage groups that participated in the project and the heritage places that were recorded and modelled.

\section{The Accord Project: research practices and methodologies}

After more than 3 decades of research and development, digital visualisation techniques, including laser scanning, photogrammetry, and reflectance transformation imaging, are now ubiquitous in the archaeology, heritage and museum sectors. However, the use of these techniques remains largely in the domain of expert forms of knowledge, informed by academic research agendas and/or professional priorities. The London Charter for ComputerBased Visualization of Cultural Heritage encapsulates this in its principles, which are intended as a 'benchmark' to ensure intellectual and technical rigour (Londoncharter.org 2009). There is a body of work relating to the use of digital media, including 3D recording and modelling, for communication, education and public engagement (for a review see King et al. 2016). However, much of this is pre-occupied with access to, and dissemination of, 
academically or professionally produced records and visualisations, again as exemplified by the London Charter (see section on 'access'). A number of projects have made significant advances in developing forms of archiving and presentation that facilitate active visitor/public engagement (King et al. 2016, 90-93), of which the Ename project was an early pioneer with its focus on interactive, collaborative storytelling (Pletinckx et al. 2003). Yet, even in such cases, the production of the digital data and visualisations involved remains predominantly in the hands of academic researchers or museum and heritage professionals, aided by interpreters, designers and digital technologists

In recent years, projects founded on citizen science and crowdsourcing have contributed to greater public/community participation in the production of digital material in heritage and museum contexts (for a discussion see King et al. [2016], Simon [2010], and contributions to Kalay et al. eds [2008]). MicroPasts, a web-enabled, crowd-sourcing project (micropasts.org) is a prominent example in the museum sector. It brings together full-time academic researchers, volunteer archaeological and historical societies and other interested members of the public to create research data (Bonacchi et al. 2014). Tasks include helping to locate artefact findspots, identifying the subject matter in historic archives, masking photos for 3D modelling, or transcribing letters and catalogues. However, more often than not, the nature of the digital research data, the role of participants, and the types of heritage involved in such projects are defined by academic researchers and/or museum and heritage professionals. Thus, in the few publications focusing on the potential of photogrammetry for facilitating community engagement with heritage, much of the emphasis is on training and the creation of a record of heritage assets (e.g. Bryan and Chandler 2008; McCarthy 2014), perpetuating expert authority in similar ways to many community archaeology projects (Smith and Waterton 2009). Furthermore, the social and communal values associated with the historic artefacts, monuments and places being recorded are rarely incorporated into the project design, let alone the creation of digital research data

In contrast, the ACCORD project team worked with ten community heritage groups across Scotland to create 3D records and models of heritage places of significance to them (Fig. 1). The aim was to examine the opportunities and implications of digital visualization technologies for community heritage practice using co-design and co-production of 3D models of historic monuments. Popular in a range of design, planning and healthcare environments, co-design and co-production methodologies are intended to decentre traditional relationships of power, control and expertise between researchers and volunteers, or 'professionals' and 'non-professionals' (Burr and Matthews 2008; Conroy et al. 2012; Cottam and Leadbeater 2006; Davies 2010). Whilst not without their challenges and shortcomings, these methodologies produce more symmetrical relationships between participants at the same time as facilitating critical reflection on the power relationships involved (see Maxwell [2017] for further discussion in the context of ACCORD; also Lynch and Alberti [2010]). 
In terms of digital visualization technologies, 'consumer-level' photogrammetry (structure from motion) and Reflectance Transformation Imaging (hereafter RTI) were used, because they are more accessible than other techniques and thus facilitate participation. Depending on the outcomes of the co-design process, time of flight laser scanning was sometimes also deployed, for example for large-scale recording. 3D printing technology was used in select cases to create physical models from the captured data. The digital data and models resulting from the project have been permanently archived on an open-access basis archived with Archaeology Data Service (doi: https://doi.org/10.5284/1042733). Issues relating to open-data and ownership of the resulting assets (intellectual property and copyright) were openly negotiated with the community groups, usually resulting in use of Creative Commons attribution licensing (CC-BY). Further technical information is also provided in the ACCORD archive (http://archaeologydataservice.ac.uk/archives/view/accord ahrc 2015/overview.cfm)

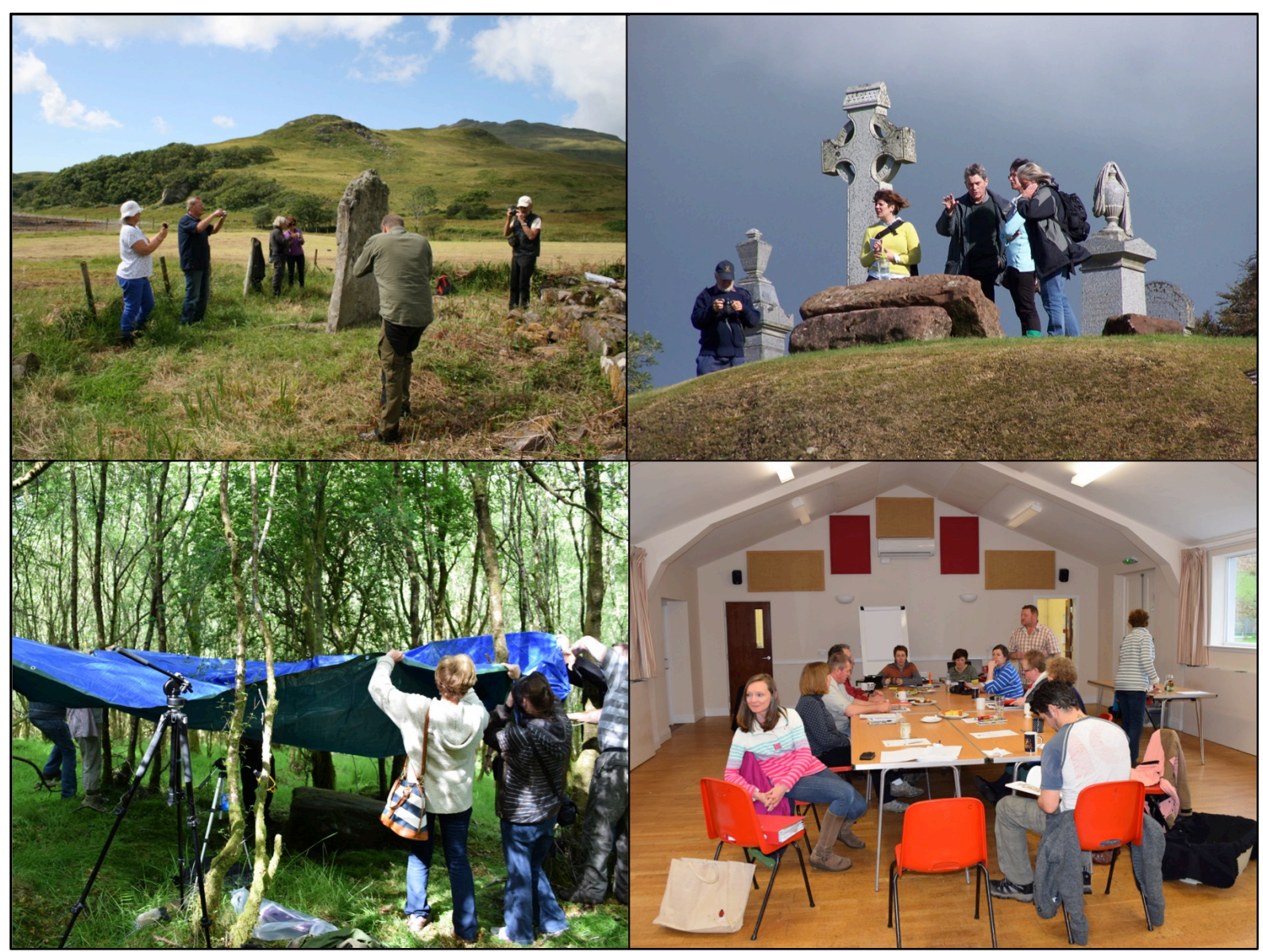

Figure 1: Co-design and co-production with community groups. Clockwise from top left: (a) photogrammetry with Ardnamurchan Community Archaeology Group; (b) co-design with Kirkcudbright Historical Society; (c) RTI and (d) focused group interview, both with and Colintraive and Glendaruel History and Archaeology Group (Images: ACCORD, CC-BY).

A distinctive aspect of the ACCORD project is that 'co-design' encouraged community participants to take an active role in the selection of recording 'targets' and technologies, with particular attention to the significance of heritage places, and the social 
and communal values associated with them. These social and communal values were also recorded and archived with the digital models. Furthermore, key research objectives included an exploration of the impact of community co-design and co-production on the value and authenticity of both the digital models and their original counterparts. For this purpose, we used qualitative research methods associated with rapid or focused ethnography, which are usually charcterised by short time-frames, mixed methods, multi-disciplinary teams, and forms of active intervention to create 'intense routes to knowing' (Pink and Morgan 2013, 351; also Knoblauch 2005). As Pink and Morgan $(2013,352)$ put it:

[Rapid ethnography] involves intensive excursions into [people's] lives, which use more interventional as well as observational methods to create contexts through which to delve into questions that will reveal matters to those people in the context of what the researcher is seeking to find out.

In the case of the ACCORD project, the co-design and co-production of $3 \mathrm{D}$ records provides an entry point or 'intervention' around which qualitative research was conducted. Our work with each group started and finished with focused group interviews (see Finch et al. 2014), which acted as points of intensive discursive enquiry where background knowledge could be obtained, and concepts and experiences relevant to the project explored and probed. The discussion was 'focused' by the project team through the use of a semi-structured interview design, but this was used flexibly to allow participants to use their own frames and concepts and to pursue their own priorities. Furthermore, the project team encouraged participants to talk to one another: "asking questions, exchanging anecdotes, and commenting on each others' experiences and points of view" (Kitzinger and Barbour 1999: 4). We also used participant observation during the co-design and co-production of the digital records and models, which facilitated intensive observation of these 'situated performances' (Knoblauch 2005, para 28).

In synopsis, the ACCORD team spent 2-3 intensive days working with each of the 10 community groups and the various methodologies were combined in 4 distinct phases (see Fig. 2). Phase 1 consisted of the first focused group interview with those members of the community heritage group who wished to engage in the accord project (Fig. 1(d)). This was designed to elicit discussion about the nature and formation of the heritage group, their interests and attachments, the heritage practices they ordinarily engage in, and the meanings and values associated with specific historic objects, monuments and places.

Phase 2 focused on co-design of the 3D recording and modelling activities. This phase consisted of a continuation of the phase 1 focus group, identifying and discussing targets and technologies for 3D visualization, often with the aid of images and maps (see Figs 6(a) and 6(b) below). In addition, co-design often entailed direct engagement with landscapes of attachment in the form of site visits and story telling (Fig. 1(b), also 5(b) below). 
Community participants and research team members worked together, taking into account the interests of the community heritage group, as well as the objectives of the ACCORD project.

Phase 3 focused on co-production, starting with field recording and then progressing to data processing and modelling. Community participants had different levels of photographic and IT proficiency, with only a handful of individuals across all of the groups with any prior experience of photogrammetry, let alone the other techniques. Members of the project team brought technical expertise and experience to the co-production, but a collaborative ethos was actively promoted with community participants engaged in photographic recording (Fig. 1(a)), screening and lighting for RTI (Fig. 1(c)), clearing vegetation, strategic discussion and management of data. Data-processing and modelling were initiated by project staff, but wherever possible conducted in the company of community participants with as much participation as possible (see Fig. 5(d) below). This phase also stimulated reflection and discussion mediated by close engagement with heritage places and direct experience of the recording practices.

\section{ACCORD Methodology}

\section{Phase 1: focused group interview}
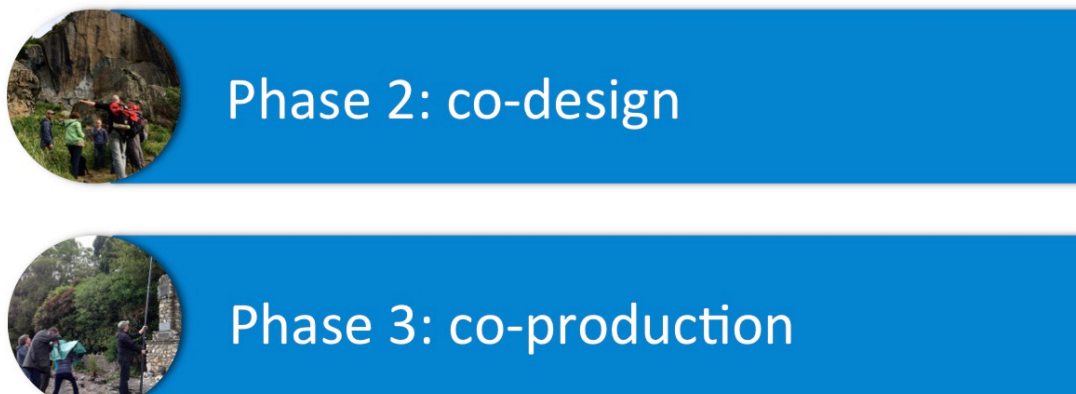

\section{Phase 3: co-production}

\section{Phase 4: focused group interview}

Figure 2: Diagram showing the key stages in the ACCORD methodology (ACCORD, CC-BY).

Phase 4 involved another focused group interview, this time exploring the significance, value and authenticity of the $3 \mathrm{D}$ visualizations, as well as their relations with 
the tangible objects and places they represent. Where forms of attachment and ownership surfaced these were actively explored, as were the aesthetics of the virtual forms produced. Discussion also focused on the practices involved and the experience of co-design and coproduction. Finally, the ways in which participation in 3D visualisation impacted on the interests and attachments of those involved was considered.

Throughout the four phases, project team members were participant observers. Jones and Maxwell, in particular took the lead in terms of this overarching ethnographic research, keeping field notes to record observations, experiences and conversations. Phases 2 and 3, where project team members and community participants engaged in collaborative practices, were particularly productive in this regard. Direct engagement with landscapes, monuments and objects during co-design and co-production often stimulated conversations and debates that provided insights into group dynamics and the ways in which value and authenticity are negotiated in practice. Participant observation also allowed the project team to gain an understanding of community participants' changing attitudes to 3D technologies and the resulting visualizations. Thus the ACCORD methodology created intense research encounters that brought theoretical questions into focus within an ethnographic arena (Pink and Morgan $2013,357)$, including those relating to significance, value and authenticity.

\section{Places of significance: community heritage practices and 3D visualisation}

The ACCORD project involved a diverse range of community groups largely drawn from pre-existing relationships with project partners. Half were recruited from Archaeology Scotland's Adopt-a-Monument Scheme, a five-year community-led scheme (with some 55 self-subscribed groups), which supports and facilitates local groups across Scotland wishing to conserve and promote their local heritage. An open call through the Scheme enlisted 5 groups to participate in ACCORD (Access Archaeology; Ardnamurchan Community Archaeology Group; Bressay History Group; Colintraive and Gendaruel History \& Archaeology Group; The Friends of Glasgow Necropolis). We recruited a further group through Glasgow Life's community outreach scheme (Castlemilk's How Old Are Yew?) and one through the Royal Commission on the Ancient and Historic Monuments of Scotland (now part of Historic Environment Scotland (HES)) (the rock climbers at Dunbarton Rock). The remaining 3 out of 10 ACCORD groups were recruited through academic and professional colleagues of the project team who were working with community archaeology or heritage groups (The Kircudbright History Society; The Rhynie Woman Group; Tarbat dig/Clan McFarlene Group).

The ten groups vary considerably in their nature, interests, size and longevity (see Table 1 for details). They include archaeology and history societies, as well as more informal groups with a strong emphasis on practical investigation, conservation and presentation of heritage places. Many of the groups are characterised by their focus on a specific locale, associated with a range of interests and activities extending beyond cultural heritage. Indeed, 
a couple of groups we worked with can best be described as 'communities of practice'; loose, emergent or transient groups, formed around particular kinds of activity and/or heritage places with little formal organisational structure.

[Table 1 - end of document]

In terms of size, the groups range from a handful of people to those with a sizeable membership, although the ACCORD team usually worked with 5-10 (self-selecting) participants from a given group. The groups are widely distributed Scotland, from the Central Belt, to Kirkcubright in the southwest, the Ardnamurchan peninsula in the West Highlands, Rhynie in the East, and the remote islands of the Uists and Bressay (see Fig. 3). These offer radically different geographic contexts associated with correspondingly diverse landscapes and forms of heritage, including densely populated urban conurbations, rural/coastal towns and villages, and dispersed Highland and Island communities. There are also significant variations in socio-economic context, ranging from Castlemilk, one of Glasgow's post-War social housing schemes, to the wealthy rural town of Kirkcudbright, to communities undergoing population decline in more remote regions. There are also some variations in age and gender, at least in terms of the individuals who participated in ACCORD. However, the most significant social distinction, for rural groups at least, is that between self-defining 'incomers' and 'locals'; a widespread category distinction in rural Scotland (e.g. Macdonald 1997a; Nadel-Klein 1991). 


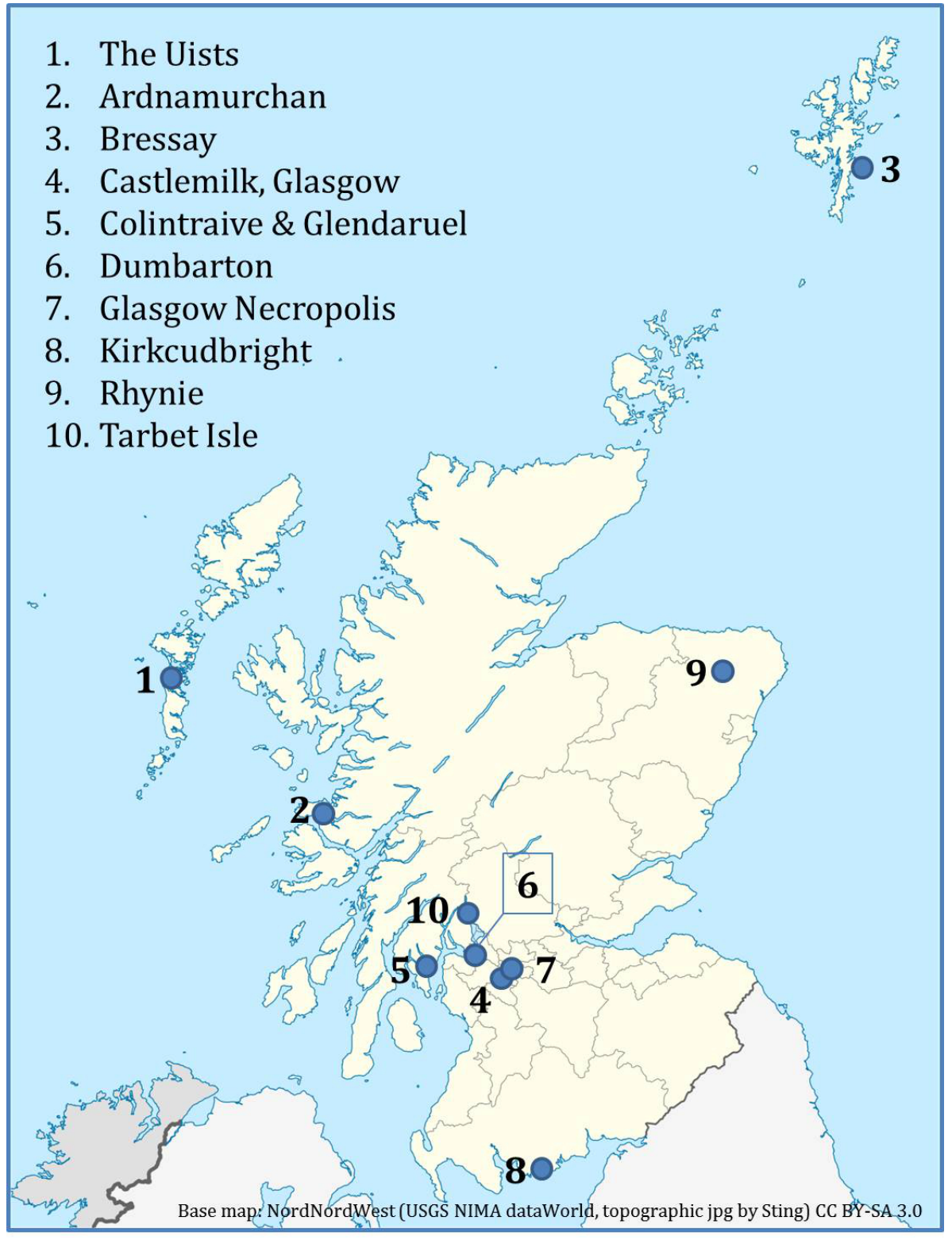

Figure 3: Location map showing the distribution of ACCORD project groups (Images: ACCORD, CC-BY).

For many of the groups, investigating, conserving and/or promoting heritage places is a means to establish connections to locality and make a place for themselves; as one participant put it, to 'get in touch through the story'. This inclination is often particularly pronounced or explicit for those who see themselves, and/or are defined by others, as 'incomers'. This also impacts on the kinds of monument people focus on. For instance, rural heritage groups with a significant proportion of 'incomers' often avoid the recent past, which is bound up in personal genealogies and oral histories, and focus on the distant past manifested in archaeological monuments to create a sense of connection for themselves.

Related processes are at work in contexts associated with a history of dislocation or displacement. For instance, the Scots-Americans involved in the Tarbet dig within the Loch Lomond and Trossachs National Park are seeking to re-connect with their clan heritage by 
actively investigating and recording what they see as their Clan MacFarlane heritage. In a very different context, for members of Castlemilk's 'How Old Are Yew?' group, investigating, recording and preserving what might be seen as the elite heritage of the former Castlemilk House offers a means to create a sense of belonging in one of Glasgow's notorious post-war housing schemes.

Another important aspect of these place-making activities is the desire to counter decline and marginalisation. The Rhynie Woman group offers another example, seeing Rhynie as 'a bit of a backwater' and their work as a means of 'putting Rhynie on the map'. Colintraive and Glendaruel History and Archaeology Group are also preoccupied with marginalisation seeing themselves as 'a community at risk' and heritage as a means of generating tourism, business and leisure; 'making something that people will want to come and see'. Indeed, countering 'risk' is an important stimulus to the place-making activities of many of the community heritage groups involved in ACCORD, whether threats take the form of vandalism, coastal erosion, or straightforward neglect.

These on-going heritage practices and the relationships associated with them framed the co-design and co-production of 3D digital heritage visualisations during the ACCORD project. The interests, agendas and values of the groups concerned, informed the heritage places we recorded and modelled, creating visualisations of 'places of significance' as defined by the groups themselves. A wide range of monuments, buildings and objects were ultimately selected for recording and visualisation (see Table 2 and Fig. 4). Among them are prehistoric monuments (such as Lephinkill Chambered tomb and Grimsay Wheelhouse) and historic buildings (such as the excavated remains of a $17^{\text {th }} / 18^{\text {th }}$ century structure on Tarbet Isle, the ruined manse in the abandoned township of Cullingsburgh (Fig. 4 (a)), or the Monteath Mausoleum in Glasgow Necropolis). There are a number of early medieval sculptured stones (Fig. 4 (d)), and a significant number of later historic gravestones. Other memorials include the Jhone MacFarlan (sic) plaque in the wall of Luss Church (Fig. 4 (c)) and the WW1 War Memorial in Colintraive (also Fig. 4 (d)). Finally there is also a range of what can be classed as art, in the form of sculptures and rock art, ranging from prehistoric cup and ring marks, to the late twentieth century sculpture King of the Castle in Castlemilk, and the graffiti associated with the climbing routes at Dumbarton Rock.

[Table 2 - end of document]

Some of the heritage places that were visualised as part of the ACCORD project are associated with family history and genealogical connections, but more frequently they relate to less direct or specific notions of inheritance and cultural continuity. Many also have a symbolic or iconic role in terms of the distinctiveness of a place and the identity of those associated with it. For instance, for the Friends of Glasgow Necropolis, the cemetery is an important symbol of the city, intimately associated with its 'illustrious' Victorian history. In a very different context, members of the Access Archaeology Group see Grimsay Wheelhouse 
as an iconic monument, distinguishing the Uists from other islands in the Outer Hebridean archipelago, as well as the rest of Scotland. Dumbarton Rock, or 'Dumby', has an iconic role in Scottish climbing heritage, symbolic of a gritty urban scene (see Hale et al. 2017, 9 and 12). As a final contrasting example, Kenny Hunter's King of the Castle Sculpture, created as part of a public art regeneration project in 1999, is symbolic of the resilience and spirit that characterise the Castlemilk community.

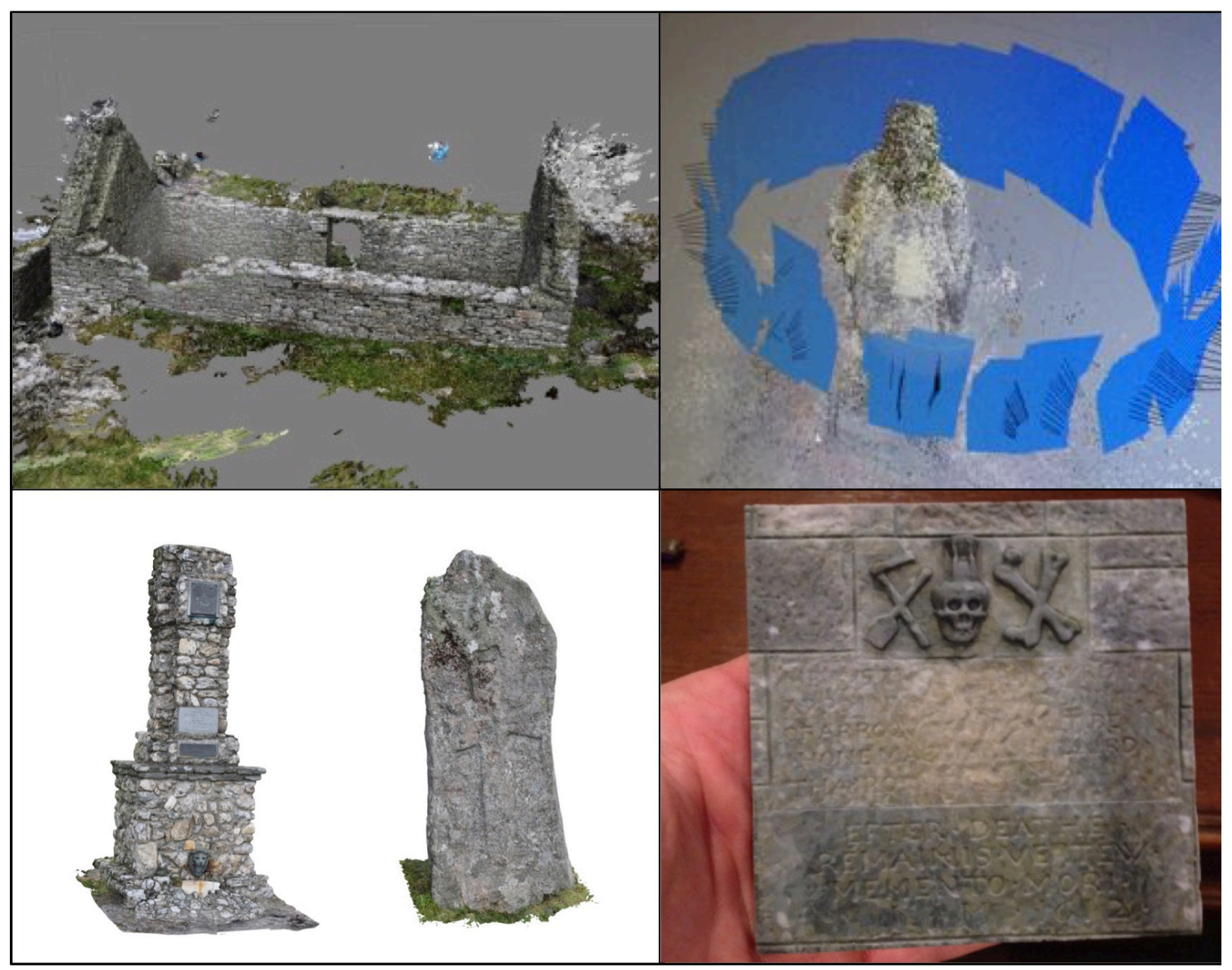

Figure 4: Some examples of ACCORD outputs in various stages of production. Clockwise from top left: (a) processing of a photogrammetric model of Cullingsburgh Manse; (b) point cloud of Falstaff showing camera positions; (c) 3D print of the MacFarlane plaque at Luss church courtesy of Preston McFarland; (d) photogrammetric visualisations of the WW1 memorial in Colintraive and the early medieval cross at Camas Nan Geall, Ardnamurchan (Images: ACCORD, CC-BY).

As we discuss in detail elsewhere, many of the social and communal values associated with these tangible heritage places 'migrate' to 3D visualisations in the context of co-production methodologies (Jeffrey et al. in prep). The ACCORD project provides clear evidence that the digital models accrue similar values to originals, becoming imbued with symbolic associations relating to identity and place. At the same time, it shows that visualisation technologies can also enhance the understanding of the original monument or object e.g. RTI can reveal inscriptions or designs that are otherwise difficult or impossible to 
identify, and photogrammetry can facilitate new perspectives and viewpoints that change people's understanding of the original historic forms. In a less direct sense 3D digital records have the potential to reinforce and enhance forms of symbolism and community identity associated with originals. Indeed, the act of digital recording in the context of community coproduction extends relations with the original metaphorically and physically, through the forms of production involved. It requires an objectification of significance, alongside concentrated forms of engagement, which are experienced communally, and which add to the cultural biography of the original historic buildings, monuments and objects involved. Thus, in the context of community co-production, 3D records and visualisations not only accrue value, they also enhance the values associated with the tangible heritage objects they represent, and in some cases even create new forms of value. But what of the ambivalent relationships between 3D digital representations and authenticity? How does community coproduction impact on the authenticity of 3D models and indeed their physical counterparts? In the next section we return to this issue.

\section{The digital and the material: experiencing and negotiating authenticity in the ACCORD project}

Preliminary responses from those involved in the ACCORD project appeared to uphold a strong distinction between digital representations and their tangible counterparts. People's initial reactions to the digital models they had created often focused on their visual impression and aesthetics, especially their realism or hyper-realism: 'it looks just like the real thing', 'it's almost more real than the original', and so forth. The apparent veracity or fidelity of the digital visualisations was central to these claims and a repeated focus of discussion, ostensibly vindicating prevailing academic concerns about the accuracy and objectivity of the digital surrogate. Furthermore, many focused on the photographic qualities of the models and their potential as forms of record for conservation and investigation. However, although these characteristics would appear to bring 3D models and visualisations closer to the realm of the authentic, in the sense of the real, the genuine and the truthful, ironically that was not the case. Indeed, explicit statements regarding the distinctiveness of the digital copy usually accompanied these discussions: 'it's not the same as the original though'; 'it could never be a substitute for the original'.

In making distinctions between original and virtual objects participants would frequently highlight characteristics of the former that are absent in the digital realm. The importance of tangibility and touch was often underlined, resonating with recent research on authenticity (e.g. Holtorf 2013; Jones 2010, 2016). As one participant put it, the original 'makes you want to touch it', whilst another emphasised that contact with the original offers a 'physical connection back to the people who make it', echoing Holtorf's $(2013,433)$ arguments about one of the key characteristics of 'pastness'. Other sensory qualities associated with the experience of tangible historic objects were also highlighted: their physical setting and wider landscape; associated sounds and smells; the weather and so forth. 
Such issues were rarely straightforward, often resulting in debate about the distinctions. For instance, one member of the Access Archaeology Group in the Uists pointed out that the 3D visualisation is 'still a representation.... It doesn't have atmosphere, the landscape, the weather'. Another member of the group immediately countered this view, asserting that 'it is a visualisation, but it is [also] a real site, it is the stone, it is the site'. This exchange was then followed by a passionate discussion about the importance of changing weather conditions and sounds, such as bird song, in the experience of historic objects, monuments and places.

The ethnographic material from the ACCORD project thus echoes recent studies that highlight the importance of sensory aspects of experience in the negotiation of authenticity. These aspects are clearly missing from the digital models and this constrains their aura and authenticity in part. However, complex relations are created between physical originals and digital models, which demonstrate that the latter are active agents in the negotiation of authenticity. Some ACCORD participants clearly felt that digital representations can take something away from their original counterparts. As one participant in the Kirkudbright group evocatively exclaimed, 'it dilutes the original!'; seemingly echoing Benjamin's point about the decay of aura. Yet, many participants highlighted the ways in which digital models offer new ways of seeing and experiencing. People talked of 'seeing more' or 'seeing differently'. Moreover, for one of the climbers we worked with at Dumbarton Rock the 3D models of the boulders and rock faces allowed him 'to experience the place differently'. Indeed despite the absence of materiality, the climbers' response to the digital models was informed by their embodied practices, and the value of the models in part lay in the way they allowed them to think through the relation between their bodies and the surfaces of the rock in new ways (Fig. 5) (for further discussion see Hale et al. 2017, 10-11).

The ability to manipulate photogrammetric models and hence gain access to new perspectives on their physical counterparts was also important to such claims about new ways of seeing and experiencing (and see Cameron 2007, 66). More commonly, these were prompted by the revelations of RTI, illuminating previously illegible inscriptions and other marks, such as the cup and ring marks recorded using this technique with the Glendaruel and Colintraive group (Fig 1(c)). As one participant exclaimed upon seeing the results of the RTI, 'I couldn't see why it was exciting and important before [...] now I see why'. In this way, as Latour and Lowe $(2011,4)$ argue, 'facsimiles, and especially those relying on complex (digital) techniques, are the most fruitful way to explore the original and even to help redefine what originality actually is'. Yet it is not just down to their ability to register and reveal 3D aspects of a thing that are invisible to the human eye. The digital object is also associated with a magical quality that animates the original. As one participant in the ACCORD project remarked, the digital visualisation 'brings it [the original] to life'. It can be argued that this also relates to the experience of authenticity; the process of digital recording and representation somehow brings those involved closer to the unique biography of the original, through forms of studied attention that highlight the marks of its production and the patina of age, even if in the form of a representation (Cameron 2007, 63; Gartski 2016, 5-6). 


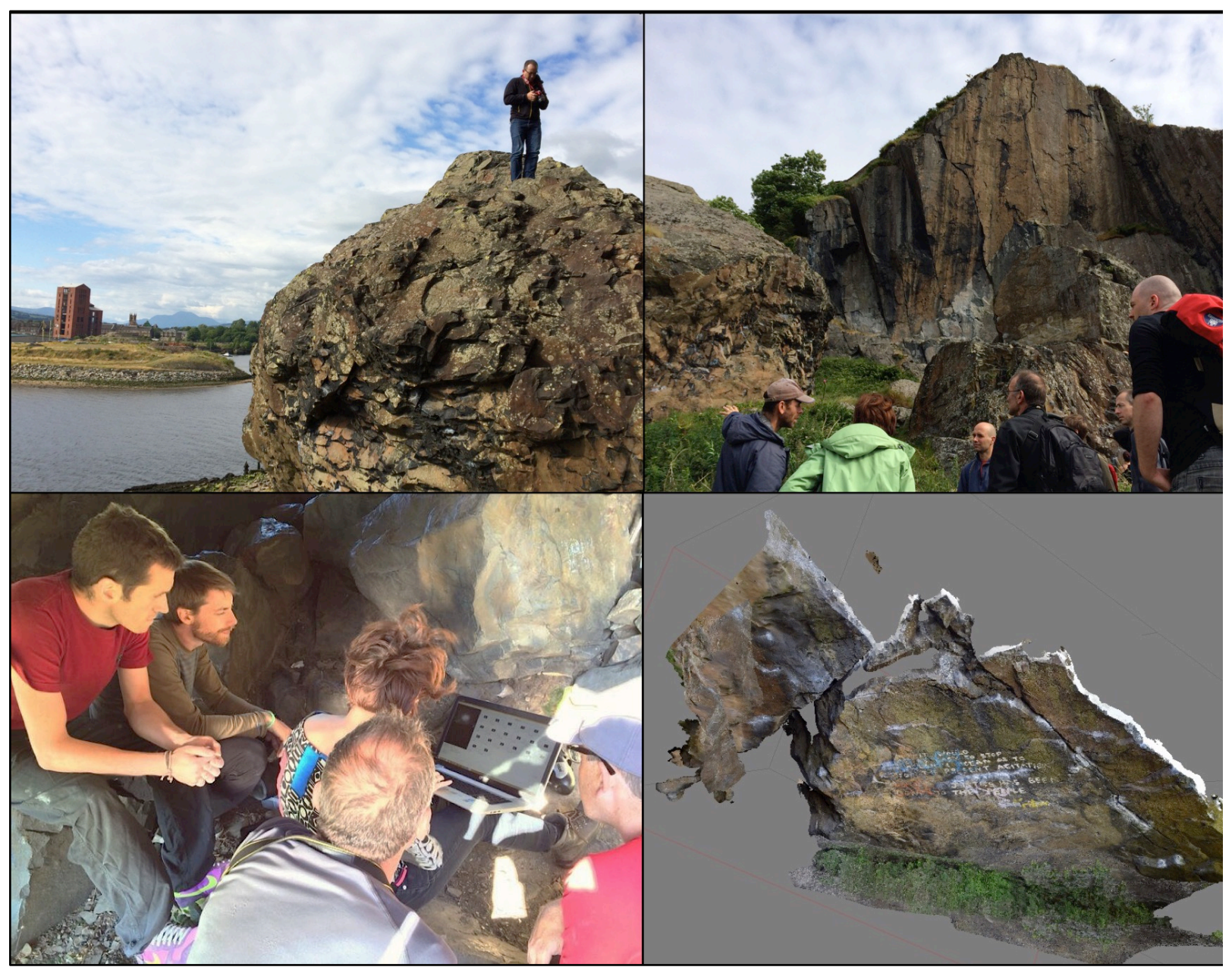

Figure 5: ACCORD work in progress with the climbers at Dumbarton Rock ('Dumby'). Clockwise from top left: (a) taking photographs of one of the boulders for photogrammetry; (b) co-design in action; (c) a photogrammetric model of Pongo boulder; (d) processing images in the field (Images: ACCORD, CC-BY).

Importantly, the act of participating in the production of 3D visualisations was a significant aspect of people's responses to the models, contributing to a sense of authenticity. The significance of 'being there' was summed up particularly succinctly by one participant in the Uist group who simply stated, 'it's authentic because we made it'. For some, the authenticity of the model was also derived from pre-existing forms of attachment and identity associated with the site they were recording and modelling. As discussed in the previous section, these visualisation practices were undertaken in landscapes that are rich in significance and the focus of existing heritage practices, and this in turn clearly contributed not just to the value of the resulting models, but also their authenticity. Thus, in the context of co-production, the productive nature of $3 \mathrm{D}$ models, and the significance of who creates them with what intention, is brought into sharp focus, creating forms of authority and aura.

At the same time, the ACCORD project shows that, in the context of community coproduction at least, 3D heritage visualisations can create, extend and reinforce networks of relations between people, monuments and places. In a number of cases, visualisation served 
to articulate and authorise relations between objects and places. For instance in recording and modelling a nineteenth-century garden statue of Falstaff (Fig 6), which is now located in Calderwood Park, the Castlemilk group were driven by a concern to reconnect the statue with its original location in the grounds of Castlemilk House. Their selection of the statue in the context of co-design was framed by previous research on the house and its grounds, in particular an historic postcard showing Falstaff standing in the gardens. Talk of requesting his physical return to Castlemilk, was transposed into the possibility of a metaphorical reappropriation through recording and modelling.

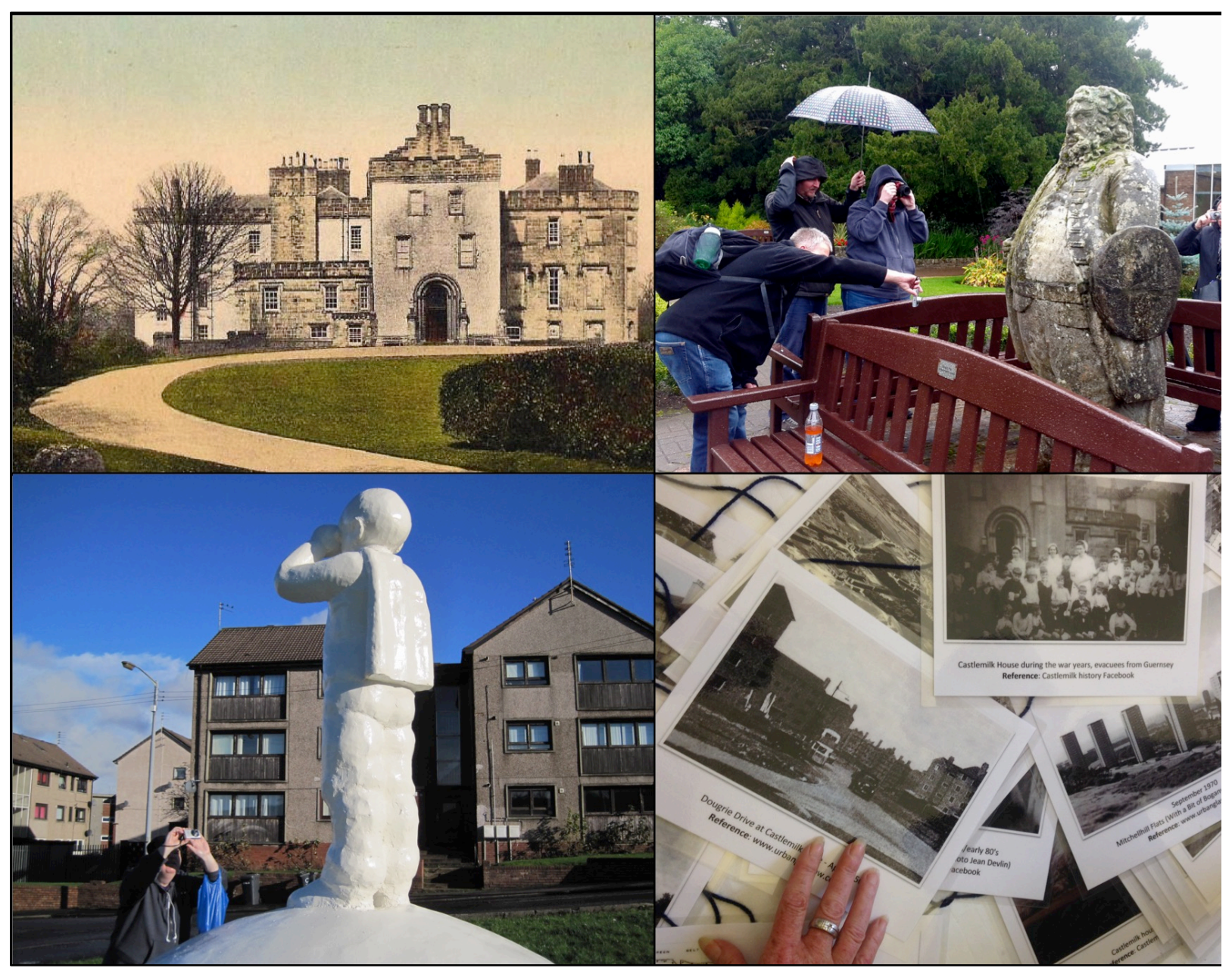

ACCORD work with Castlemilk's 'How Old Are Yew?' group. Clockwise from top left: (a) photograph of Castlemilk House as pictured on an Edwardian postcard; (b) recording the statue of Falstaff; (c) old photographs of Castlemilk collected by the group; (d) a member of the group taking photographs of Kenny Hunter's sculpture, 'King of the Castle', for photogrammetry (Images: ACCORD, CC-BY).

Thus 3D visualisation can provide a mechanism for negotiating relations of attachment and belonging, as discussed by Brown (2007) in relation to Maori objects in museums. At the same time, whilst the Castlemilk example apparently centres on the relationship between objects and places, it also needs to be understood in terms of relationships between people and place set against the experience of postwar urban renewal and displacement. In coupling Falstaff - a nineteenth-century monument that has been 
displaced - with the 'King of the Castle' sculpture (1999) - a monument resulting from a public art project celebrating Castlemilk's modern housing estate - the Castlemilk group were actively engaged in reinforcing their own connections to place (Fig 6). The 'wee rascal', as 'King of the Castle' is affectionately known locally, is an icon of Castlemilk, 'everyone knows it!' As one person explained, he 'tells of the regeneration story', which is so important in terms of transforming Castlemilk from an economically deprived housing scheme on the outskirts of a Glasgow into a place of significance (Fig. 6(c)).

There are many other examples from the ACCORD project that demonstrate how 3D recording and modeling became caught up in the negotiation of authentic relationships between people and places, past and present. One of the most obvious is the way in which the Scots-Americans who participated in the Tarbet Isle excavations saw 3D visualisation as a means to authenticate their own relationships to the MacFarlane Clan. 3D visualisation and printing focused on the wall footings uncovered by an excavation Tarbet Isle (James 2015), as well as the seventeenth-century plaque in memory of Jhone MacFarlan (sic) located in the wall of Luss Church (also known as St Kessog's Church) (Fig 4(c)). For the two MacFarlane participants (who also funded the excavations on Tarbet Isle) creating virtual models captured the act of 'being there', in the heart of what they see as MacFarlane country, even though the status of the Tarbet Isle structure as a Clan MacFarlane stronghold remained unsubstantiated. It was also felt that the virtual models would enable others in the Clan MacFarlane Society back home in the USA to connect to their ancestors remotely. For one participant $3 \mathrm{D}$ printing became key to this process, as he explained in a subsequent blog article in language saturated with allusions to authenticity:

\footnotetext{
Photogrammetry combined with 3D printing is an incredibly special technology which can be used to permanently capture and preserve the real world $[\ldots] 3 \mathrm{D}$ printing has allowed me to bring some of that homeland and history back with me. This makes it easier for people to discover, understand, and fall in love with their heritage. They can now hold in their hand a scaled reproduction of a building or some other artefact. (McFarland cited in Krassenstein 2014)
}

Whilst such explicit statements are music to the ears of commercial ventures like 3DPrint.com and others, the ACCORD project also reveals more complex and subtle negotiations at stake in 3D recording. For instance, in the case of other groups the creation of $3 \mathrm{D}$ records and visualisations provided a means for self-defined 'incomers', with no prior connections to the rural communities they have settled in, to create a sense of connection for themselves. Doing photogrammetry and RTI required them to devote time and studied attention to a specific place, but it also served to incorporate them into the biography of that place through their authorship of a virtual model. Thus, in the context of co-production the practices involved in the use of 3D technologies create networks of relationships between historic objects, people and places that become part of the biography of the virtual object and mediate the experience of authenticity for all involved. 
Digital objects thus become caught up in the cultural politics of authentication. The selection of an object, building or monument for recording and modeling creates meaning and value and extends networks of relationships across time and place. For instance, members of the Kirkcudbright History Society selected various headstones in the Kirkcudbright Kirkyard as a means to show how the cemetery, which was subject to vandalism in 2010, is a cherished part of the community (Fig 1(b)). The decision of the Colintraive and Glendaruel group to model a neglected and forgotten memorial to two brothers who died at Gallipoli was an act of reinstating them in local social memory at a time of wider commemoration of WW1 (Fig. 4(d)). For one member of the ACCORD group, who had just returned from 20 years in Australia, it also became a personal project of reinstatement allowing him to make a meaningful connection between Australia and his new home through his subsequent investigation of the lives of the brothers and their deaths at Gallipoli.

Three final brief examples demonstrate the power of visualisation to endorse (or not) forms of heritage that have an ambivalent status in terms of authenticity. As discussed above, for the climbers we worked with at Dumbarton Rock, visualizing the climbing boulders and rock faces provided a means of incorporating 'Dumby's' place in Scottish climbing heritage into the wider discourses of authenticity surrounding the monument, including controversially the graffiti that adorns the rock surfaces (Fig 5(c)). In contrast, with Grimsay Wheelhouse, members of the Uists' Access Archaeology Group recognised that in the eyes of archaeologists and heritage professionals, the 3D model might authenticate what is regarded as a controversial reconstruction based on the excavations of a lone local amateur. Nevertheless, this awareness did not ultimately undercut their desire to model the wheelhouse, which as an iconic type of monument distinguishing the Uists from other places. Perhaps the most decisive example of the authenticating role of 3D recording is found in the case of the Bressay Stone, the original of which is now part of National Museums Scotland, located in Edinburgh. In this case, the idea of recording and modelling a physical replica that stands in its place on Bressay was dismissed, because it was felt that visualisation would lend it undue value and authenticity and reinforce the rights of the museum in regard to the original.

It would thus appear that digital visualisations have a role in mediating the experience of authenticity for those involved in their production. Whilst digital models may lack the visceral thrill of being in the presence of the original, they can create new sets of relations with their physical counterparts that gives the models a magical, alluring quality, and this in turn suggests a partial if limited migration of aura. 3D models also acquire new forms of authenticity, because recording and modeling is a creative process, and thus the product acquires a form of aura in relation to the networks of relations involved in their production. Yet above all, it is clear that $3 \mathrm{D}$ visualisations do important authenticating work, becoming 
active agents in the negotiation of relations between people, places and things, as well as the cultural politics that inform those relations.

\section{Conclusion}

The results of the ACCORD project make a significant contribution to theories of authenticity and have important implications for heritage visualisation practice. Much of the theoretical debate currently focuses on the accuracy of the data and/or the realism of the resulting 3D visualisations. Flynn $(2007,350)$ points out that 'in virtual heritage, an algorithmically accurate large-scale 3D model of a cathedral or castle is taken as the hallmark of authenticity'. A long-standing 'technological fetishism' (Huggett 2004) reigns where claims to objectivity and authenticity are removed from the producer and located with the technology itself (Gartski 2016, 15). Furthermore, notions of 'digital surrogacy' are commonplace (Rabinowitz, 2015; Gartski 2016), but because of their potential for successful imitation digital historic objects are also conceived as a source of threat to the authentic original object (Cameron 2007, 51). The London Charter for the Computer-based Visualisation of Cultural Heritage thus stresses the need to distinguish between 'fact and fiction' in heritage visualization, to make visible 'the limitations of knowledge' (Denard 2012). Furthermore, in museums and heritage organisations, much work is devoted to preserving the authority and authenticity of the original over the digital (Cameron 2007, 52). Nevertheless, all too often the productive or creative nature of 3D visualisation, embodied in acts of selection, manipulation and interpretation, remains obscure in the presentation of the final models (Cameron 2007, 56; also Gartski 2016; Rabinowitz 2015).

The ACCORD project takes questions of authenticity and 3D visualisation into a new arena - that of community heritage practice. Using rapid ethnographic approaches, combined with co-production of 3D models of historic objects, buildings and monuments, we have explored when and how digital visualisations acquire authenticity. There is evidence for some 'migration of aura' (Latour and Low 2011,4) in that the digital 'copy' becomes part of the trajectory of original and its continually re-written biography. The meanings, values, attachments and agendas that informed the selection and creation of visualisations during the ACCORD project ensured a partial, if at times limited, migration of authenticity. Yet we also agree with Cameron $(2007,67)$ that $3 \mathrm{D}$ visualisation is a creative work in its own right and thus 'the digital acts as testimony to its own history and origin, and hence authenticity'. Community co-production of 3D digital models, in which their history and provenance is explicitly tied to those involved in their design and creation, shows very clearly that they can acquire aura and authenticity independently. In this way digital visualisations embody networks of relations between objects, people and places, as Deger $(2016,128)$ has argued for 'thick photography'. These networks in turn are central to the production and negotiation of authenticity, whether in relation to material or digital objects (Jones 2010; Jones and Yarrow 2013; Macdonald 2013). 
The key point here is that a pre-occupation with the virtual object-and the binary question of whether it is or is not authentic-obscures the wider work that digital objects do. There is strong evidence from the ACCORD project that the creation of digital models can actively mediate the authenticity and status of their original counterparts. Visualisation is also incontrovertibly caught up in the work of remediation that goes on around heritage places, in particular the wider cultural politics of ownership, attachment, place-making and regeneration. Thus seeing the authenticity of digital 3D models simply as a facet of their accuracy, objectivity or realism is a misplaced venture. Instead, we echo Gilling's (2005) argument that it would be far more profitable to see it as a property of the relationships between people and their world.

These conclusions have a number of implications for the use of heritage visualization in practice. In providing benchmark standards, The London Charter (2009) stresses that 'sufficient information should be documented and disseminated to allow computer-based visualisation methods and outcomes to be understood and evaluated'. This includes documenting knowledge-claims, research sources, methods, formats and standards. However, there needs to be more attention to who was involved in the production of specific visualisations, their relationships to the original historic objects involved, and the social, economic and political conditions under which visualisations are produced. Furthermore, whilst access and communication are given considerable weight in the Charter, the emphasis is very much on stewardship and the dissemination of expert knowledge to public audiences. In the current version, there is no mention of public participatory methods, nor the potential value of co-design and co-production.

Based on the results of the ACCORD project we argue that the design and production of heritage visualisations should include a consideration of the wider cultural politics and social relations surrounding the original historic objects, as well as the production of digital records and models (see Brown 2007; Deger 2016). Communities of interest and practice should be consulted and where possible included in co-design and co-production of visualisations alongside academics, heritage professionals, designers and digital technologists. Furthermore, documentation should include a record of these relationships, and associated interests and practices, making these accessible to those who view heritage visualisations. For examples of how this can be achieved see the statements of significance archived with the ACCORD data (Jeffrey et al. 2017). These proposals shift the emphasis from product to process, but they would also enhance the significance of the products. The meaning, value and authenticity of digital heritage visualisations would be enhanced and their relationship to the unfolding biographies of their historic counterparts sustained. Importantly, such developments should also facilitate a richer dialogue about what is at stake in the images and experiences we produce about the past.

\section{Acknowledgements}


First and foremost we would like to thank all our community participants who made this research possible. Thanks also to the ACCORD project partners: Archaeology Scotland, the Royal Commission on the Ancient and Historic Monuments of Scotland (now part of Historic Environment Scotland) and Glasgow Life. Various colleagues facilitated the project and we are grateful to Gordon Noble and Richard Jones for introducing us to two of the community groups, and in particular Heather James who invited us to carry out ACCORD research during the MacFarlane excavations on Tarbet Isle. Thanks to Sam Alberti and Sally Foster for their insightful comments on a draft version of this paper. We would also like to thank the two anonymous reviewers for their constructive criticism and suggestions. This work was supported by the Arts and Humanities Research Council, Grant AH/L007533/1.

\section{References}

Benjamin, Walter. 1969 [1936]. "The Work of Art in the Age of Mechanical Reproduction." In Illuminations, edited by Hannah Arendt, trans. Harry Zohn, 217-51. New York: Schocken Books.

Bolter, Jay D., Blair MacIntyre, Maribeth Gandy, and Petra Schweitzer. 2006. "New Media and the Permanent Crisis of Aura." Convergence 12(1): 21-39. doi: https://doi.org/10.1177/1354856506061550

Bonacchi, Chiara, Andrew Bevan, Daniel Pett, Adi Keinan-Schoonbaert, Rachael Sparks, Jennifer Wexler, and Neil Wilkin. 2014. "Crowd-sourced Archaeological Research: The MicroPasts Project." Archaeology International 17: 61-68, doi: http://dx.doi.org/10.5334/ai.1705

Brown, Deidre. 2007. "Te Ahu Hiko: Digital Cultural Heritage and Indigenous Objects, People and Environments." In Theorizing Digital Heritage: A Critical Discourse, edited by Fiona Cameron and Sarah Kenderdine, 77-92. Cambridge, Mass.: MIT Press.

Bruner, Edward B. 2007. "Abraham Lincoln as Authentic Reproduction: a Critique of Postmodernism." In Museums in a Material World, edited by Simon J. Knell, 301-19. London: Routledge

Bryan, Paul G., and Jim H. Chandler. 2008. "Cost-Effective Rock-Art Recording within a Non- Specialist Environment." The International Archives of the Photogrammetry, Remote Sensing and Spatial Information Sciences 37(B5): 259-264.

Burr, Jacob, and Ben Matthews. 2008. "Participatory Innovation." International Journal of Innovation Management 12(3): 255-73. 
Cahn, Edgar S., and Christine Gray. 2012. "Co-Production from a Normative Perspective.” In New Public Governance, the Third Sector and Co-Production, edited by Victor Pestoff, Taco Brandsen and Bram Verschuere, 129-144. Abingdon: Routledge.

Cameron, Fiona. 2007. "Beyond the Cult of the Replicant: Museums and Historical Digital Objects - Traditional Concerns, New Discourses" In Theorizing Digital Heritage: A Critical Discourse, edited by Fiona Cameron and Sarah Kenderdine, 49-76. Cambrideg, Mass.: MIT Press.

Conroy, Mervyn, Harriet Clarke, and Lynne Wilson. 2012. Connected Health and Social Care Communities. Swindon: AHRC.

Cottam, Hilary, and Leadbeater, Charles. 2006. Co-Creating Outcomes. London: Design Council.

Davies, Sue M. 2010. “The Co-production of Temporary Museum Exhibitions.” Museum Management and Curatorship 25(3): 305-321. doi:

https://doi.org/10.1080/09647775.2010.498988

Deger, Jennifer. 2016. “Thick Photography.” Journal of Material Culture 21(1): 111-132. doi: https://doi.org/10.1177/1359183515623312

Denard, Hugh. 2012. "A New Introduction to the London Charter." In Paradata and Transparency in Virtual Heritage, edited by Anna Bentkowska-Kafel, Drew Baker and Hugh Denar, 57-71. London: Routledge. Accessed online:

http://www.londoncharter.org/introduction.html, 21/08/2017

Dicks, Bella. 2000. Heritage, Place and Community. Cardiff: University of Wales Press

Douglas-Jones, Rachel, John Hughes, Siân Jones, and Thomas Yarrow. 2016. "Science, Value and Material Decay in the Conservation of Historic Environments." Journal of Cultural Heritage, Advance Online Publication, doi: https://doi.org/10.1016/j.culher.2016.03.007

Finch, Helen, Jane Lewis, and Caroline Turley. 2014. "Focus Groups." In Qualitative Research Practice: A Guide for Social Science Students and Researchers, edited by Jane Ritchie, Jane Lewis, Carol McNaughton Nicholls, and Rachel Ormston, 211-242. London: Sage.

Foster, Sally M., and Neil G.W. Curtis. 2015. "The Thing about Replicas-Why Historic Replicas Matter." European Journal of Archaeology, Advance Online Publication: 1-27. doi: https://doi.org/10.1179/1461957115Y.0000000011 
Flynn, Bernadette. 2007. "The Morphology of Space in Virtual Heritage." In Theorizing Digital Heritage: A Critical Discourse, edited by Fiona Cameron and Sarah Kenderdine, 349-68. Cambridge, Mass.: MIT Press

Fyfe, Gordon. 2004. "Reproduction, Cultural Capital and Museums: Aspects of the Culture of Copies." Museum and Society 2(1): 47-67.

Garstki, Kevin. 2016. "Virtual Representation: the Production of 3D Digital Artefacts." Journal of Archaeological Theory and Method. Advance Online Publication. doi: https://doi.org/10.1007/s10816-016-9285-z

Gillings, Mark. 2005. "The Real, the Virtually Real, and the Hyperreal: The Role of VR in Archaeology." In Envisioning the Past: Archaeology and the Image, edited by Sam Smiles and Stephanie Moser, 223-239. Blackwell Publishing Ltd, Oxford, UK. doi: https://doi.org/10.1002/9780470774830.ch12

Hale, Alex, Alison Fischer, John Hutchinson, Stuart Jeffrey, Siân Jones, Mhairi Maxwell, and John Stewart Watson. 2017. "Disrupting the Heritage of Place: How Counter Archaeologies were Practiced by the ACCORD Project at Dumby, Scotland." World Archaeology. Advance online publication. doi: https://doi.org/10.1080/00438243.2017.1333923

Holtorf, Cornelius. 2013. "On Pastness: a Reconsideration of Materiality in Archaeological Object Authenticity.” Anthropological Quarterly 86(2): 427-443.

Holtorf, Cornelius, and Tim Schadla-Hall. 1999. "Age as Artefact: on Archaeological Authenticity." European Journal of Archaeology 2(2): 229-47.

Huggett, Jeremy. 2004. "Archaeology and the New Technological Fetishism. Archeologia e Calcolatori 15: 81-92.

James, Heather. 2015. Tarbet Isle, Loch Lomond, Argyll and Bute, Scotland. Northlight Heritage Report 121. Glasgow: Northlight.

Jeffrey, Stuart. 2015. "Challenging Heritage Visualisation: Beauty, Aura and Democratisation.” Open Archaeology 1: 144-152. doi: https://doi.org/10.1515/opar-20150008

Jeffrey, Stuart, Alex Hale, Cara Jones, Siân Jones, and Mhairi Maxwell. 2015. "The ACCORD project: Archaeological Community Co-Production of Research Resources." In Proceedings of the 42nd Annual Conference on Computer Applications and Quantitative 
Methods in Archaeology, CAA 2014, edited by François Giligny, François Djindjian, L. Costa, Paola Moscati and S. Robert, 1-7. Paris: CAA.

Jeffrey, Stuart, Alex Hale, Cara Jones, Siân Jones, and Mhairi Maxwell. 2017. ACCORD: Archaeology Community Co-production of Research Data [data-set]. York: Archaeology Data Service [distributor] https://doi.org/10.5284/1042733

Jeffrey, Stuart, Siân Jones, Mhairi Maxwell, Alex Hale, and Cara Jones. In Prep. "Heritage Visualisation as Community Engagement: Making Place, Creating Value.”

Jones, Siân. 2010. "Negotiating Authentic Objects and Authentic Selves: Beyond the Deconstruction of Authenticity." Journal of Material Culture 15(2): 181-203. doi: https://doi.org/10.1177/1359183510364074

Jones, Siân. 2016. "Unlocking Essences and Exploring Networks: Experiencing Authenticity in Heritage Education Settings.” In, C. van Boxtel, M. Grever, and S. Klein (eds) Sensitive Pasts. Questioning Heritage in Education, 130-52. Oxford: Berghahn

Jones, Siân, and Thomas Gresham Yarrow. 2013. "Crafting Authenticity: an Ethnography of Conservation Practice.” Journal of Material Culture 18(1): 3-26.

Kalay, Yehuda, Thomas Kvan, and Janice Affleck eds. 2008. New Heritage: New Media and Cultural Heritage. London: Routledge.

King, Laura, James F. Stark, and Paul Cooke, 2016. "Experiencing the Digital World: the Cultural Value of Digital Engagement with Heritage." Heritage and Society 9(1): 76-101.

Krassenstein, Eddie. 2014. "3D Printing Allows Man to Preserve and Replicate a Piece of Family History in Incredible Fashion." 3DPrint.com, https://3dprint.com/26369/3d-printedfamily-stone/

Kitzinger, Jenny, and Rosaline S. Barbour. 1999. "Introduction: the Challenge and Promise of Focus Groups." In Developing Focus Group Research, edited by Rosaline S. Barbour and Jenny Kitzinger, 1-21. London: SAGE. doi: https://doi.org/10.4135/9781849208857.n1

Knoblauch, Hubert. 2005. "Focused Ethnography." Forum Qualitative Sozialforschung / Forum: Qualitative Social Research, 6(3), Art. 44, http://nbn-resolving.de/urn:nbn:de:0114fqs0503440

Latour, Bruno, and Adam Lowe. 2011. "The Migration of the Aura, or How to Explore the Original through its Facsimiles.” In Switching Codes: Thinking Through Digital Technology 
In The Humanities And The Arts, edited by Thomas Bartscherer and Roderick Coover, 27598. Chicago: University of Chicago Press.

Lindholm, Charles. 2008. Culture and Authenticity. Oxford: Blackwell.

Londoncharter.org, 2009. London Charter for Computer-Based Visualization of Cultural Heritage. http://www.londoncharter.org/

Lynch, Bernadette T., and Sam J.M.M. Alberti. 2010. "Legacies of Prejudice: Racism, CoProduction and Radical Trust in the Museum." Museum Management and Curatorship 25(1): $13-35$.

Maxwell, Mhairi. 2017. "Power is in the Process: The ACCORD project." Internet Archaeology 44. https://doi.org/10.11141/ia.44.10

McCarthy, John. 2014. "Multi-Image Photogrammetry as a Practical Tool for Cultural Heritage Survey and Community Engagement.” Journal of Archaeological Science 43: 175185. doi: https://doi.org/10.1016/j.jas.2014.01.010

Macdonald, Sharon. 1997a. Reimagining Culture: Histories, Identities and Gaelic Resistance. Oxford: Berg.

Macdonald, Sharon. 1997b. “A People's Story: Heritage, Identity and Authenticity.” In: Touring Cultures: Transformations of Travel and Theory, edited by Chris Rojek and John Urry, 155-75. London: Routledge.

Macdonald, Sharon. 2013. Memorylands: Heritage and Identity in Europe Today. London: Routledge.

Nadel-Klein, Jane. 1991. "Reweaving the Fringe: Localism, Tradition and Representation in British Ethnography." American Ethnologist 18(3): 500-15.

Oxford English Dictionary 2002. Oxford: University of Oxford Press.

Pink, Sarah, and Jennie Morgan. 2013. "Short-Term Ethnography: Intense Routes to Knowing." Symbolic Interaction 36 (3): 351-361. doi: https://doi.org/10.1002/SYMB.66

Pletinckx, Daniel, Neil Silberman, and Dirk Callebaut. 2003. "Heritage Presentation through Interactive Storytelling: A New Multimedia Database Approach." The Journal of Visualization and Computer Animation 14: 225-231. doi: https://doi.org/10.1002/vis.319 
Rabinowitz, Adam. 2015. "The Work of Archaeology in the Age of Digital Surrogacy." In Visions of Substance: 3D Imaging in Mediterranean Archaeology, edited by Brandon R. Olson and William R. Caraher, 27-42. Grand Forks, ND: The Digital Press at the University of North Dakota.

Simon, Nina. 2010. The Participatory Museum. http://www.participatorymuseum.org/, accessed August 14, 2017.

Smith, Laurajane, and Emma Waterton. 2009. Heritage, Communities and Archaeology. London: Duckworth. 


\begin{tabular}{|c|c|c|c|}
\hline $\begin{array}{l}\text { Community } \\
\text { Group }\end{array}$ & $\begin{array}{l}\text { Rural/ } \\
\text { Urban }\end{array}$ & $\begin{array}{l}\text { Geographical } \\
\text { focus }\end{array}$ & Description (constitution, history, interests etc) \\
\hline $\begin{array}{l}\text { Access } \\
\text { Archaeology Group }\end{array}$ & $\begin{array}{l}\text { Remote } \\
\text { rural }\end{array}$ & $\begin{array}{l}\text { N. \& S Uist, } \\
\text { Outer Hebrides }\end{array}$ & $\begin{array}{l}\text { A small informal archaeology group (5-10 regulars) active } \\
\text { since } 2014 \text {. The core group met trough an Archaeology } \\
\text { evening course. They regularly volunteer for SCHARP. All } \\
\text { are resident in the Uists, but most are self-defined } \\
\text { 'incomers'. }\end{array}$ \\
\hline $\begin{array}{l}\text { Ardnamurchan } \\
\text { Community } \\
\text { Archaeology Group }\end{array}$ & $\begin{array}{l}\text { Remote } \\
\text { rural }\end{array}$ & $\begin{array}{l}\text { Ardnamurchan } \\
\text { Peninsula, } \\
\text { Highland }\end{array}$ & $\begin{array}{l}\text { A small local archaeology group (6 regulars) initially } \\
\text { stimulated by an archaeological project in the area. } \\
\text { Officially formed in } 2013 \text { after participation in an } \\
\text { Archaeology Scotland workshop. Most members are self- } \\
\text { defined resident 'incomers'. }\end{array}$ \\
\hline $\begin{array}{l}\text { Bressay History } \\
\text { Group }\end{array}$ & $\begin{array}{l}\text { Remote } \\
\text { rural }\end{array}$ & $\begin{array}{l}\text { Bressay, } \\
\text { Shetland Islands }\end{array}$ & $\begin{array}{l}\text { A small, but relatively long-standing group (10 regulars), } \\
\text { which is a registered Scottish Charity. The group founded } \\
\text { the Bressay Heritage Centre (opened 1996). Members } \\
\text { represent a mix of self-defined 'locals' and 'incomers'. }\end{array}$ \\
\hline $\begin{array}{l}\text { How Old Are } \\
\text { Yew? }\end{array}$ & Urban & $\begin{array}{l}\text { Castlemilk, } \\
\text { Glasgow }\end{array}$ & $\begin{array}{l}\text { A free local interest group (5-10 members) focusing on } \\
\text { Castlemilk heritage, incl. archaeology and nature. Organized } \\
\text { by the Castlemilk Woodland Officer. Most participants } \\
\text { live/grew up in the post-War social housing scheme. }\end{array}$ \\
\hline $\begin{array}{l}\text { Colintraive and } \\
\text { Glendaruel History } \\
\text { and Archaeology } \\
\text { Group }\end{array}$ & Rural & $\begin{array}{l}\text { Cowell } \\
\text { peninsula, } \\
\text { Argyll }\end{array}$ & $\begin{array}{l}\text { A sub-committee of the C\&G Development Trust with } 40 \\
\text { official members. Activities of the group centre on the } \\
\text { community-owned Stronafian Forest. Members of the } \\
\text { history group are mostly self-defined 'incomers'. }\end{array}$ \\
\hline $\begin{array}{l}\text { Rock-climbers at } \\
\text { Dumbarton Rock } \\
\text { ('Dumby') }\end{array}$ & Urban & $\begin{array}{l}\text { Dumbarton } \\
\text { Rock, W. } \\
\text { Dunbartonshire }\end{array}$ & $\begin{array}{l}\text { A fluid, informal community of practice/interest centred on } \\
\text { bouldering and climbing on the NW side of Dumbarton } \\
\text { Rock. Predominantly a non-local group, recently galvanized } \\
\text { to action in response to perceived threat to climbing } \\
\text { heritage. }\end{array}$ \\
\hline $\begin{array}{l}\text { The Friends of the } \\
\text { Glasgow } \\
\text { Necropolis }\end{array}$ & Urban & Glasgow & $\begin{array}{l}\text { A registered Scottish Charity formed in } 2005 \text { focusing on } \\
\text { preserving, developing and promoting Glasgow Necropolis. } \\
\text { There is a diverse international fee-paying membership (c. } 80 \\
\text { people) though active members are Glasgow-based. }\end{array}$ \\
\hline $\begin{array}{l}\text { The Kirkcudbright } \\
\text { History Society }\end{array}$ & $\begin{array}{l}\text { Rural } \\
\text { town }\end{array}$ & $\begin{array}{l}\text { Kirkcudbright, } \\
\text { Dumfries and } \\
\text { Galloway }\end{array}$ & $\begin{array}{l}\text { A formal fee-paying society established in } 2001 \text {. There are c. } \\
80 \text { members. The Society has engaged in more pro-active } \\
\text { conservation since } 2010 \text { in response to vandalism at } \\
\text { Kirkcudbright Old Kirkyard. }\end{array}$ \\
\hline $\begin{array}{l}\text { The Rhynie } \\
\text { Woman group }\end{array}$ & Rural & $\begin{array}{l}\text { Rhynie, } \\
\text { Aberdeenshire }\end{array}$ & $\begin{array}{l}\text { A small informal group of creative practitioners ( } 6 \text { founding } \\
\text { members) focusing on Rhynie heritage. Currently drafting a } \\
\text { constitution and seeking official status as a charity. Members } \\
\text { live locally but most are self-defined 'incomers'. }\end{array}$ \\
\hline $\begin{array}{l}\text { Tarbet Isle Dig } \\
\text { Project }\end{array}$ & Rural & $\begin{array}{l}\text { Tarbet Isle \& } \\
\text { Luss } \\
\text { Churchyard, } \\
\text { Loch Lomand }\end{array}$ & $\begin{array}{l}\text { A transient grouping formed around an excavation directed } \\
\text { by Northlight Heritage. Funded by two Scots-Americans; } \\
\text { active members of Clan MacFarlane Worldwide (c. } 1,200 \\
\text { members). Other participants were amateur archaeologists. }\end{array}$ \\
\hline
\end{tabular}

Table 1: ACCORD Community Groups 


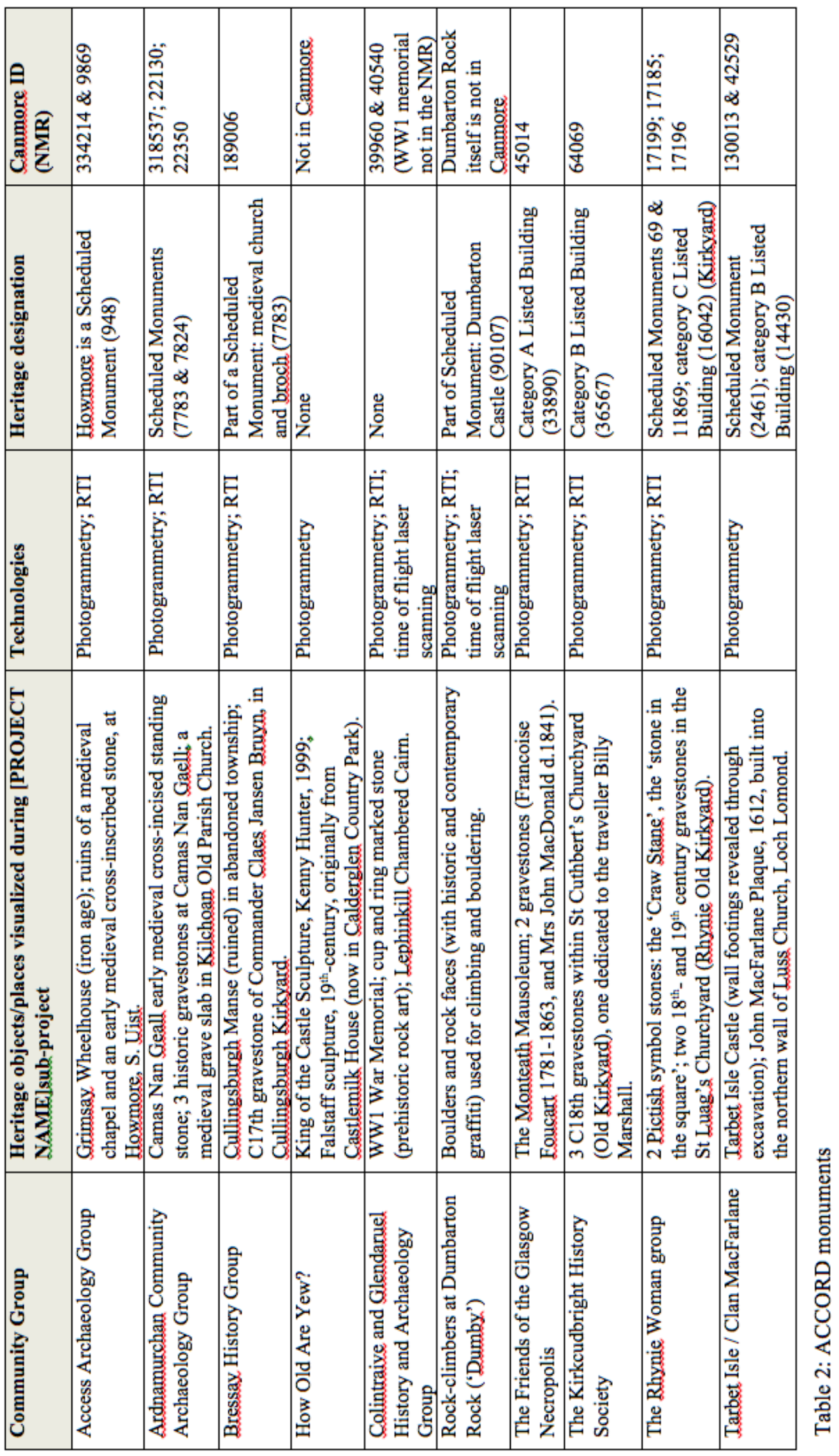

